\title{
Frequency Control of Isolated Power System with Wind Farm by Using Flywheel Energy Storage System
}

\author{
Rion Takahashi \\ Kitami Institute of Technology \\ Japan
}

\section{Introduction}

For the recent expansion of renewable energy applications, wind energy generation is receiving much interest all over the world. Many large wind farms have been installed so far and recently huge offshore wind farms have also been installed. However, the frequency variation of power system due to wind generator output fluctuations is a serious problem. If installations of wind farms continue to increase, frequency control of power system by the main sources, that is, hydraulic and thermal power stations, will be difficult in the near future, especially in an isolated power system like a small island which has weak capability of power regulation. In such a case, the installation may be restricted even though it is a small wind farm. Though there is such a difficulty, an introduction of the wind energy utilization is much effective in an isolated power system, because main power plant in a small island is mostly a diesel engine driven generating plant and it has no good effect on the environment. Hence, some strategies are necessary to improve the stability of wind farm output. According to such situations, an application of battery system for the output power smoothing has been investigated so far, and some experimental studies using practical facilities are being performed. The battery system is suitable for power compensation with relatively long period like load leveling. However, since rapid response is necessary to compensate power variations in an isolated power system, the battery system may not be appropriate because charging or discharging speed of the battery is not so fast due to its chemical process. Moreover, the same capacity of electronic power converter as that of the battery power rating is required. In addition life time of battery is, in general, not so long and thus frequent replacement of battery cell will be needed. These characteristics cause cost increase. On the other hand, the application of Flywheel Energy Storage System (called 'FESS' hereinafter) for power compensation is very effective. This system has characteristics of large energy storage capacity, long life, and rapid response of power control. It has a heavy weight rotating mass connected to an adjustable speed generator. This chapter adopts an adjustable speed generator with secondary AC excitation as a driving machine of rotating mass, because this type of generator has already been put into practice in pumped storage hydro power plants in Japan [1]. There are also some practical applications of FESS to improve power system stability [2]. The adjustable speed generators with secondary AC excitation can control not only active power output but also reactive power output rapidly 
and independently. Thus smoothing of both output power and grid voltage fluctuations in wind farm is possible by installing FESS with the adjustable speed generator. In addition, since only small capacity of electronic power converter is needed in this system, the total cost can be decreased. Therefore, the FESS can be effective on smoothing of wind farm output fluctuation, resulting in the frequency stabilization of the power system.

With these points as background, this chapter proposes a control strategy of FESS to reduce the frequency variation in an isolated power system including a wind farm. The main features are as follows: 1) Cooperation with the main power plant, i.e., output of the main power plant is adjusted in co-operation with the FESS depending on its energy charge level; 2) Direct frequency control. In the case of large power system, generally, smoothing of rapid change of wind farm output in short period is performed by energy storage system, while slow change in long term is absorbed by other power plants for frequency control. However in the isolated power system, single or a few main source generators can hardly regulate slow power fluctuation. Therefore direct frequency control by energy storage system is desirable. In order to evaluate the effectiveness of the proposed method, computer simulation analyses are performed by using PSCAD/EMTDC [3].

\section{Example of model system}

\section{Overview of FESS operation}

Fig. 1 shows an overview of FESS operation proposed in this chapter. The isolated power system consists of main power supply, a consumer load and a wind farm. FESS is installed near the wind farm. FESS detects the network frequency and stabilizes it by supplying or absorbing active power to/from the network. FESS also sends a command to the main power supply to adjust its output so as to keep suitable stored energy level of FESS.

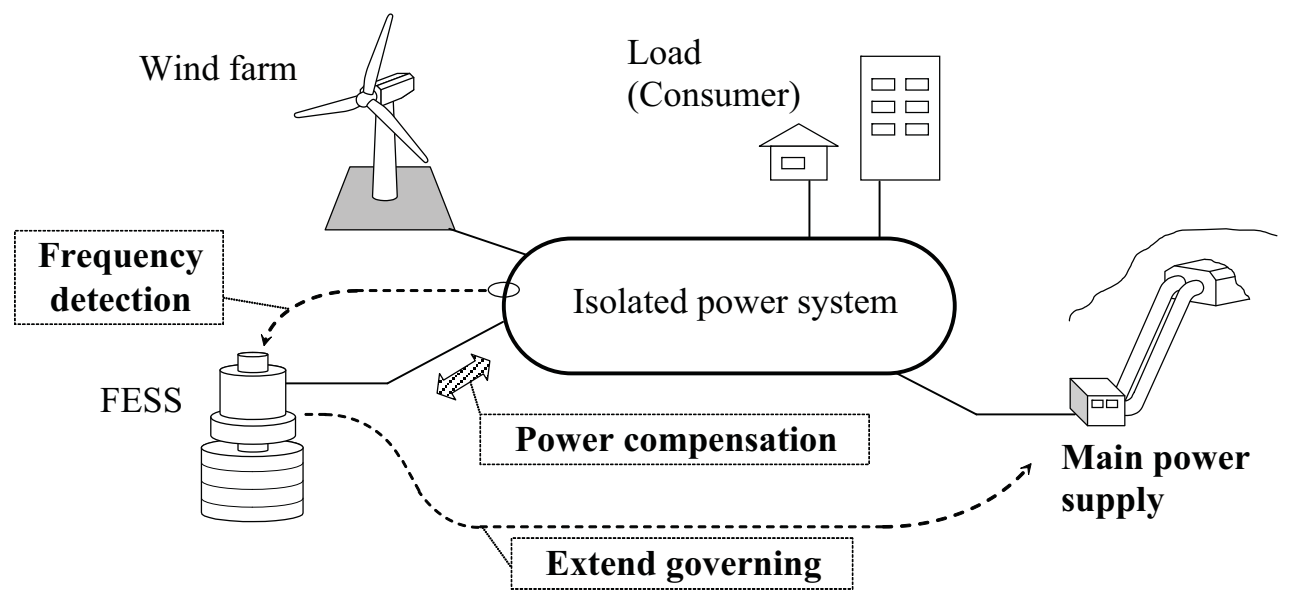

Fig. 1. Overview of FESS operation

\section{Brief configuration of power system}

Fig. 2 shows the power system model used in this chapter. A Wind Farm (WF) is modeled by a single induction generator with a wind turbine operating almost at constant speed. The FESS is installed to the grid point of wind farm. A Synchronous Generator (SG) as a main 
source generator which is driven by a diesel engine is connected to the grid point through a transmission line, and resistive loads are connected to the both ends of the line.

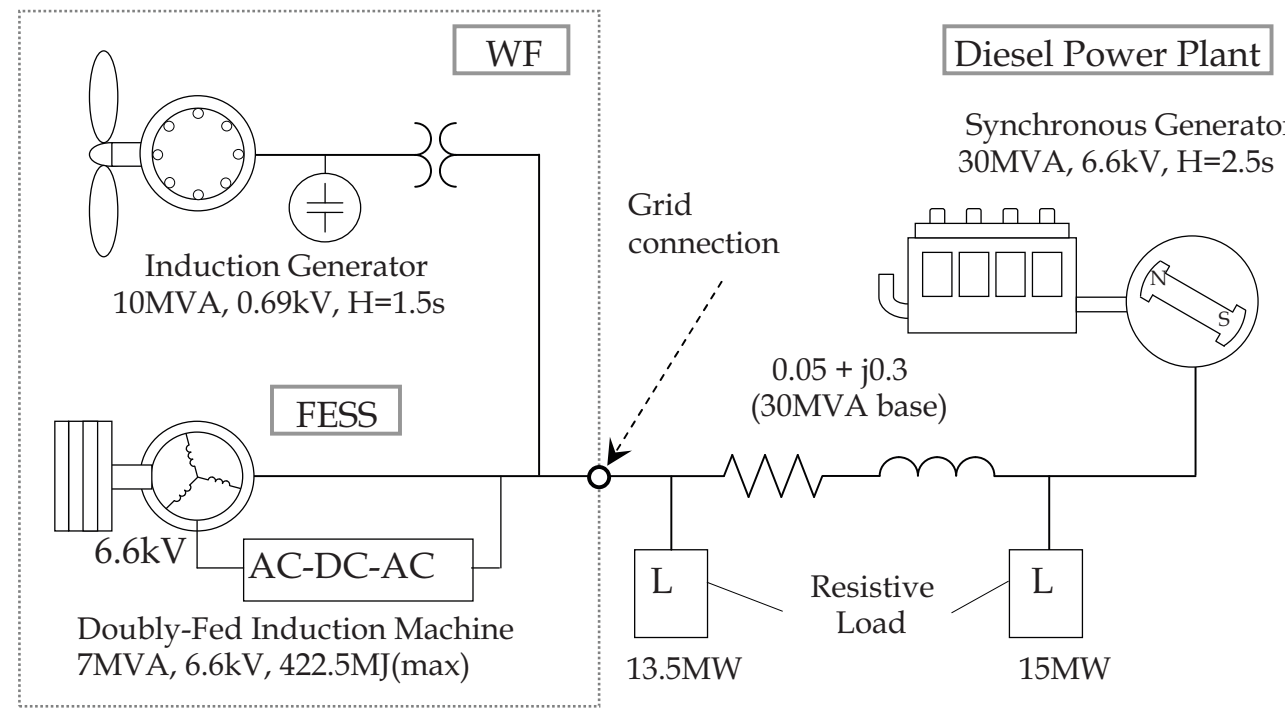

Fig. 2. Model system of an isolated power system

\section{Configuration of FESS}

Fig. 3 shows a model configuration of FESS. The FESS consists of the adjustable speed generator, the flywheel mass for kinetic energy storage, and secondary excitation circuit for adjustable speed control [4]. The adjustable speed generator has basically the same construction as that of a wound rotor induction machine. The secondary excitation power is supplied from the terminal of FESS, and converted to DC power by the converter, then again converted to low frequency AC power by the inverter and supplied to the rotor. Thus, the rotor can rotate at asynchronous speed. The inverter controls active and reactive power output $\left(\mathrm{P}_{\mathrm{T}}\right.$ and $\left.\mathrm{Q}_{\mathrm{T}}\right)$ of the generator, and the converter controls $\mathrm{DC}$ link voltage $\mathrm{E}_{\mathrm{DC}}$ and reactive power $\mathrm{Q}_{\mathrm{L}}$ flowing into the secondary excitation circuit. These electronic power converters are modeled as 6 force-commutated power switches connected in a bridge configuration as shown in Fig. 4. A sinusoidal PWM operation is carried out and switching signals are generated by applying triangular carrier wave comparison. Conventional PI controllers are used for the inverter and the converter control as shown in Fig. 5 and 6 respectively. Parameters of the FESS generator are shown in Table II.

\section{A method of frequency stabilization by using FESS}

The main purpose of this study is to reduce the network frequency variation by using FESS. The configuration of the control system for the frequency stabilization is shown in Fig. 7.

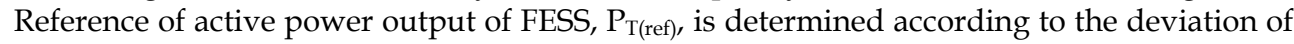
network frequency, which is detected by PLL at the terminal of FESS. When the frequency is decreased, FESS supplies active power to the network. When the frequency is increased, FESS absorbs active power from the network. These control schemes correspond to block (A) in Fig. 7. At the same time, $\mathrm{P}_{\mathrm{T}(\mathrm{ref})}$ is modified to prevent a shortage or an excess of the 
Doubly-Fed Induction Machine (7MVA, 6.6kV, $\mathrm{H}=50.0)$

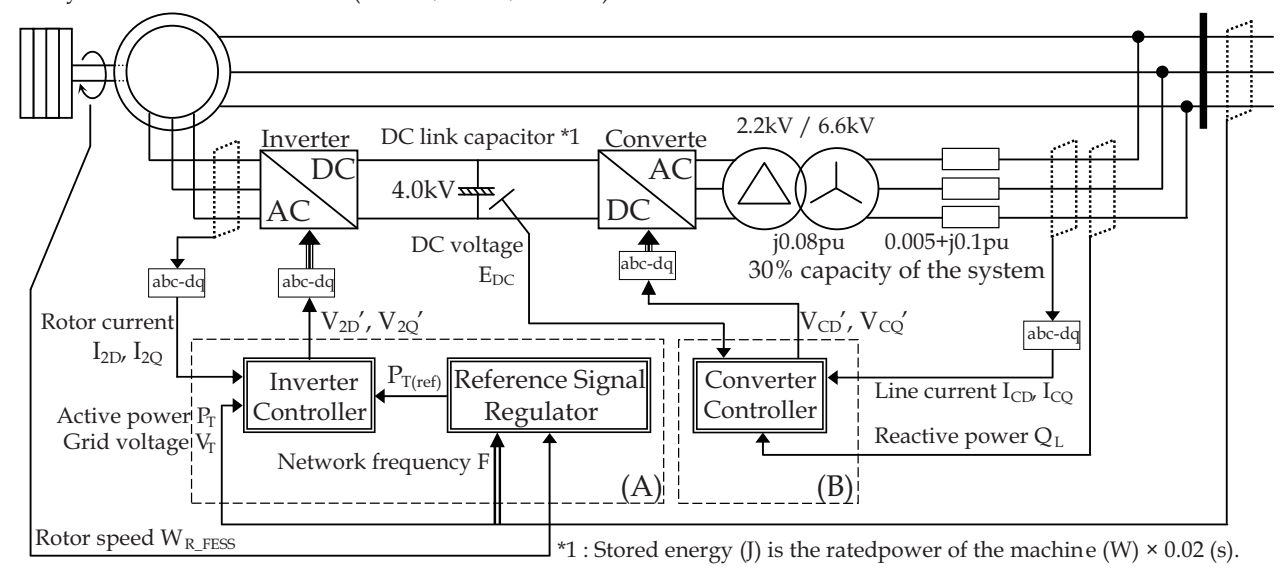

Fig. 3. FESS circuit configuration

stored energy of FESS. In this study, the maximum and the minimum rotor speeds of FESS are specified $130 \%(1.3 \mathrm{pu})$ and $70 \%(0.7 \mathrm{pu})$ of the rated speed respectively. Considering these boundary speeds, the value of $\mathrm{P}_{\mathrm{T}(\mathrm{ref})}$ is modified to a lower (or a higher) value when the rotor speed is under (or over) 1.044pu, at which the stored energy becomes a half of the maximum storage energy. These control schemes correspond to block (B) in Fig. 7. Fig. 7 also includes a rule of FESS control to avoid operating under $0.7 \mathrm{pu}$ or over 1.3pu rotor speed as shown in Table I.

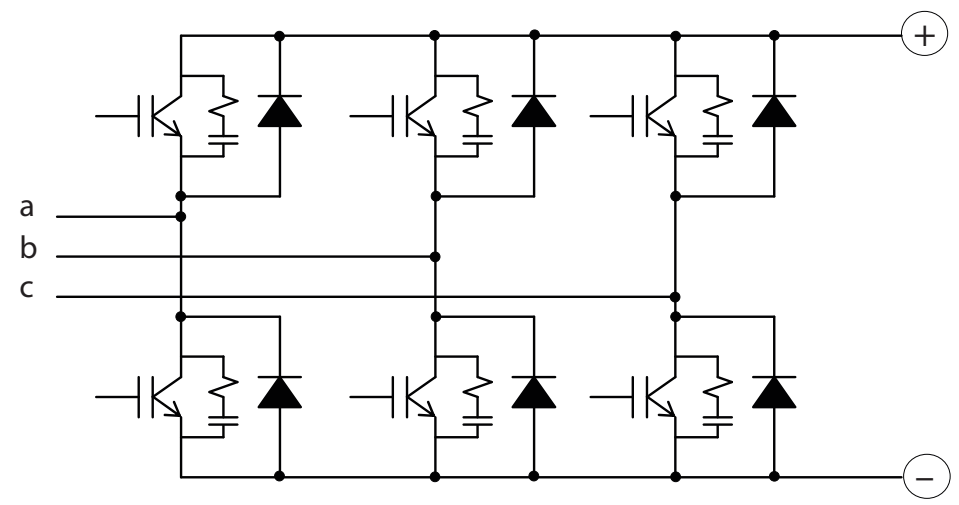

Fig. 4. Model of power converter

\begin{tabular}{ccc|c|c}
\hline & & & Frequency $<50$ & Frequency $>50$ \\
\hline & $W_{\text {R_FESS }}$ & $>1.3$ & 1 & 0 \\
\hline $1.3>$ & $W_{\text {R_FESS }}>0.7$ & 1 & 1 \\
\hline $0.7>$ & $W_{\text {R_FESS }}$ & 0 & 1 \\
\hline
\end{tabular}

Table I. Rule of FESS control 


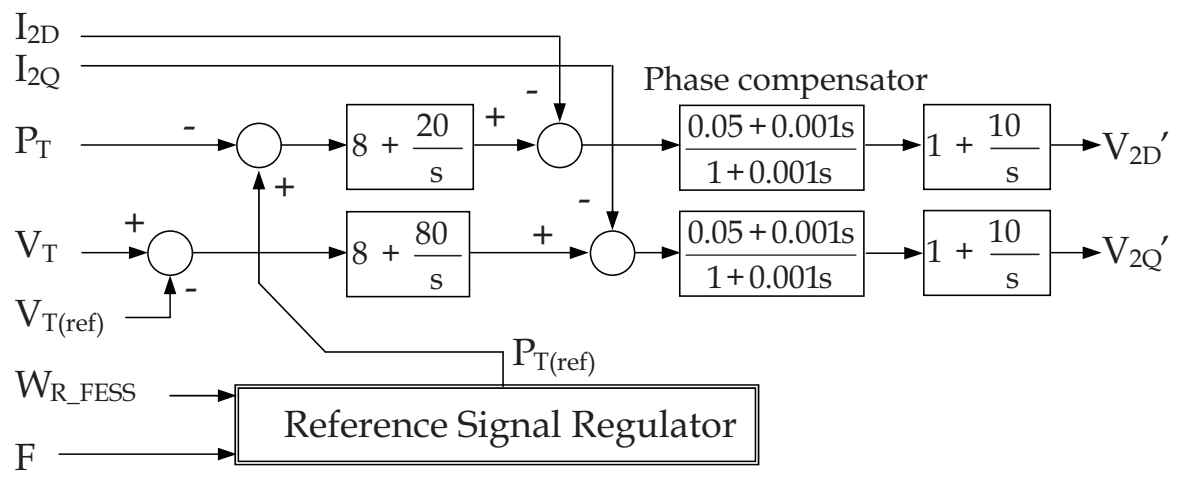

Fig. 5. Output power controller of FESS

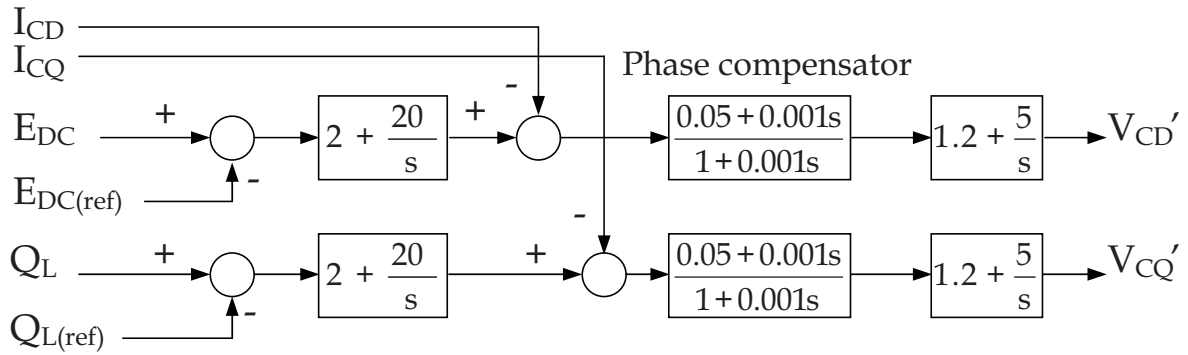

Fig. 6. Excitation power controller of FESS

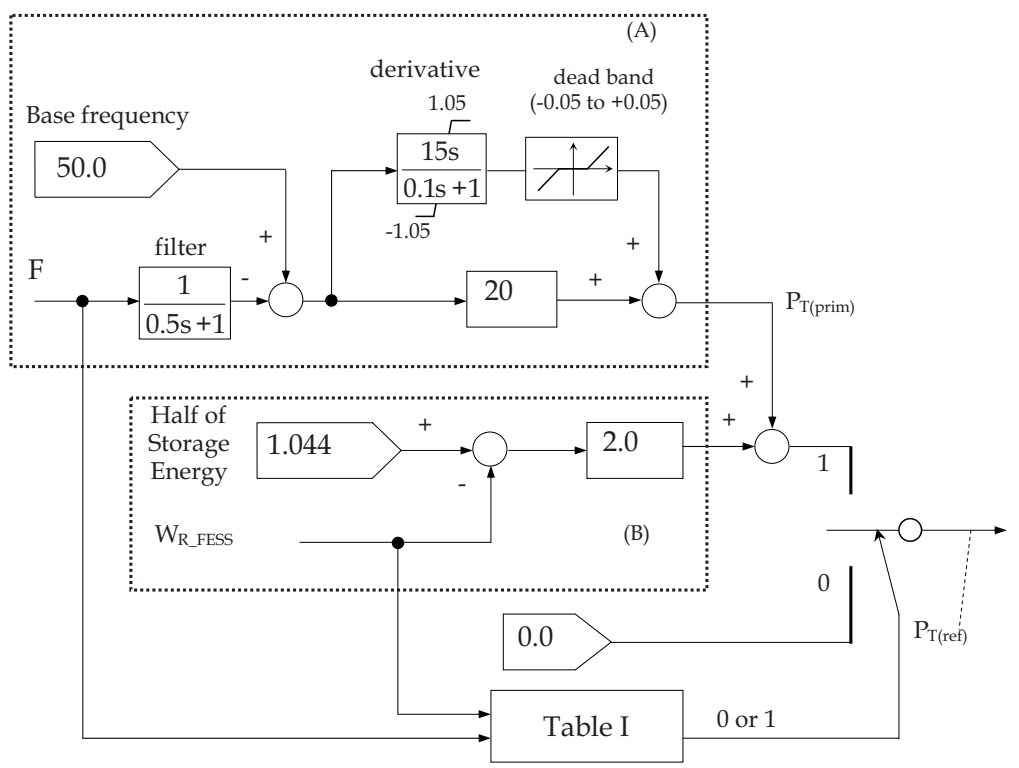

Fig. 7. Reference signal controller for frequency stabilization 


\section{Wind farm model}

The wind farm consists of an induction generator and a wind turbine. An aerodynamic characteristic of the turbine blade expressed by eqs. (2) and (3) is adopted [5]. The captured power is expressed by eq.(1). Since the induction generator is operated at almost constant speed (approx. 1.0 to $1.01 \mathrm{pu}$ ), the output power changes widely with respect to wind speed variations. Generally, a wind turbine is equipped with a pitch angle controller. The conventional pitch controller shown in Fig. 8, that maintains the output of the generator to be the rated power when the wind speed is over the rated speed, is also considered in this study. Parameters of the wind generator (IG) are shown in Table II.

$$
\begin{gathered}
P_{M}=\frac{1}{2} \rho C_{p}(\lambda) \pi R^{2} V_{W}^{3}[W] \\
C_{p}(\lambda)=0.5\left(\Gamma-0.0 .2 \beta^{2}-5.6\right) e^{-0.17 \Gamma} \\
\Gamma=\frac{R}{\lambda} \cdot \frac{3600}{1609}
\end{gathered}
$$

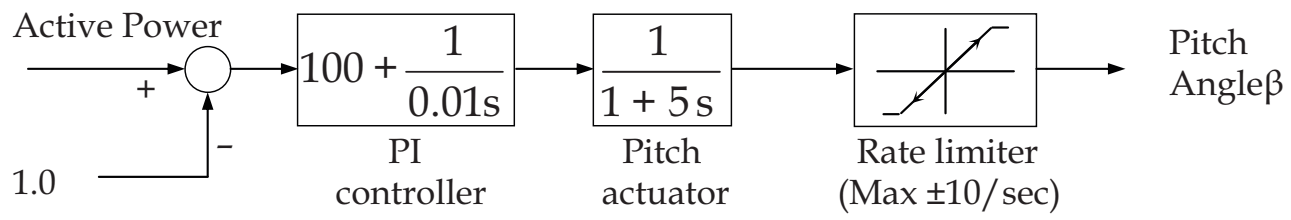

Fig. 8. Pitch angle controller of wind turbine

\begin{tabular}{rcc}
\hline & IG & FESS \\
\hline Stator resistance $(\mathrm{pu})$ & 0.01 & 0.02 \\
Stator leakage reactance $(\mathrm{pu})$ & 0.07 & 0.08 \\
Magnetizing reactance $(\mathrm{pu})$ & 4.1 & 3.5 \\
Rotor resistance $(\mathrm{pu})$ & 0.007 & 0.02 \\
Rotor leakage reactance $(\mathrm{pu})$ & 0.07 & 0.08 \\
\hline
\end{tabular}

Table II. Parameters of induction machines.

\section{Synchronous generator model}

A Synchronous Generator (SG) is considered as a main power supply unit in the network in this study, which is assumed to be a diesel engine driven power plant. The characteristics of the diesel engine and its governor system in [6] are considered. The governor controls fuel supply to maintain the engine speed at the synchronous speed. Its block diagram is shown in Fig. 9, and its parameters are shown in Table III. 
If FESS regulates the network frequency by its power compensation, the output of SG may not change, because the network frequency is controlled to be constant. Consequently, there is a possibility that FESS performs all of the network frequency control instead of SG. In such case, when the stored energy in FESS becomes full or empty, the power balance of the network cannot be maintained and thus the network frequency can deviate significantly. To avoid such situation, the output of SG also needs to be regulated according to the stored energy of FESS. In this chapter, a cooperative control is proposed, in which the output of SG is increased (or decreased) when the rotor speed of FESS is below (or over) 1.044pu which corresponds to a half of the maximum storage energy of FESS. But if the additional command to the main source generator changes fast, its output will also vary widely, and then it suffers large mechanical stress. Therefore a control gain is set for the additional command to change slowly as shown in Fig. 10. The governor of SG in this study has been designed to control only engine speed, and thus the output of SG can be changed by modifying a monitored signal of the engine speed to the governor. These control systems are shown in Fig. 10. In addition, a simple AVR model shown in Fig. 11 is used in SG model. Parameters of the synchronous generator (SG) are shown in Table IV.

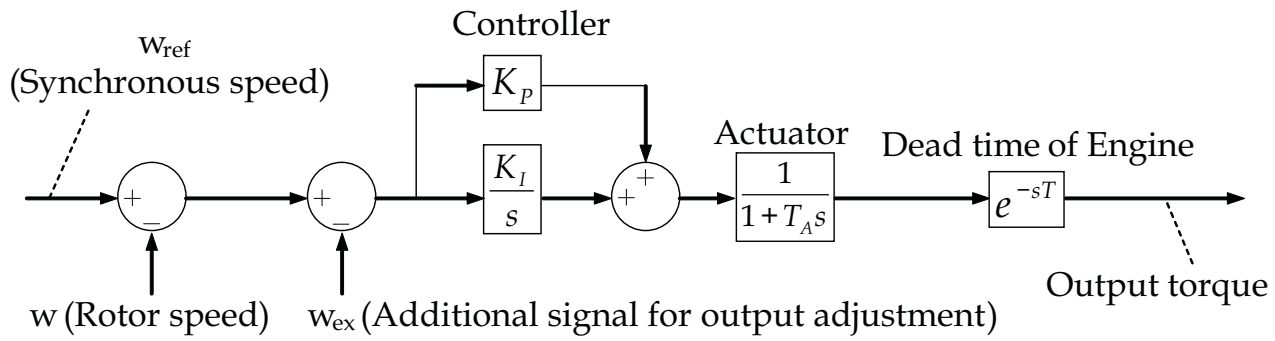

Fig. 9. Governor model of the diesel engine

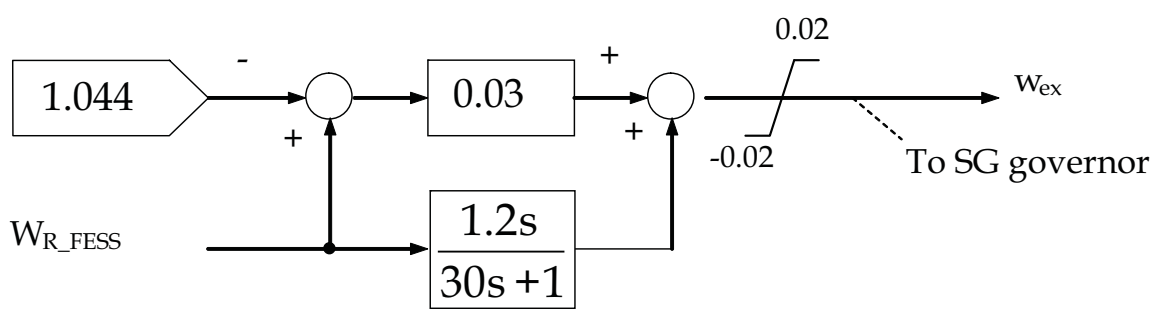

Fig. 10. Additional signal controller for output adjustment of the diesel engine 


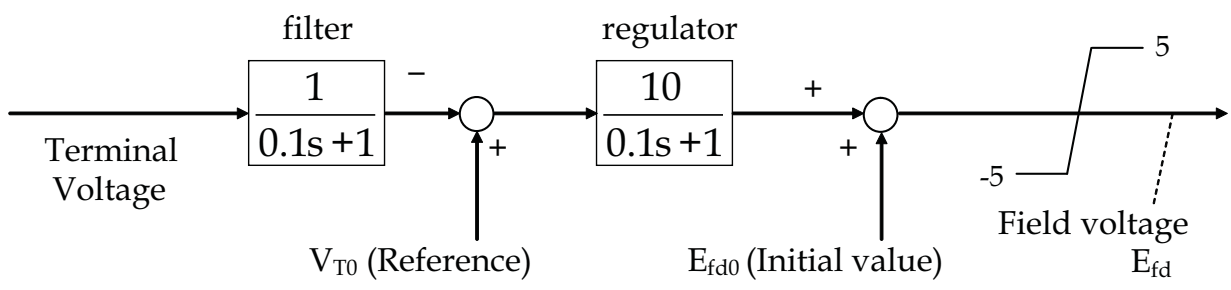

Fig. 11. AVR model of the synchronous generator

\begin{tabular}{rc}
\hline Proportional Gain of $\mathrm{K}_{\mathrm{P}}$ & 8.0 \\
Integral Gain $\mathrm{K}_{\mathrm{I}}$ & 2.0 \\
Pilot servo time constant $\mathrm{T}_{\mathrm{A}}$ & $0.2 \mathrm{~s}$ \\
Dead time of engine $\mathrm{T}$ & $0.25 \mathrm{~s}$ \\
\hline
\end{tabular}

Table III. Parameters of the diesel engine governor

\begin{tabular}{|c|c|c|}
\hline Armature resistance $(\mathrm{pu})$ & \multicolumn{2}{|c|}{0.0025} \\
\hline Stator leakage reactance $(\mathrm{pu})$ & \multicolumn{2}{|c|}{0.14} \\
\hline Field resistance (pu) & \multicolumn{2}{|c|}{0.0004} \\
\hline \multirow[t]{2}{*}{ Field leakage reactance (pu) } & \multicolumn{2}{|c|}{0.2} \\
\hline & D-axis & Q-axis \\
\hline Magnetizing reactance (pu) & 1.66 & 0.91 \\
\hline Damper resistance (pu) & 0.005 & 0.0084 \\
\hline Damper leakage reactance (pu) & 0.044 & 0.106 \\
\hline
\end{tabular}

Table IV. Parameters of synchronous generator. 


\section{Simulation example}

\section{A. Condition}

A determination of the energy storage capacity is very important for designing energy storage system. In this chapter, the energy storage capacity of FESS is determined from a point of view of adequate frequency control ability but reducing it as small as possible. The power rating of FESS is decided as $70 \%$ of that of the wind farm since instantaneous output change of the wind farm can hardly reach its power rating in normal operation.

Comparative study between the proposed frequency control method (shown in Fig. 7 and Table I) and a power smoothing method (shown in Fig. 12 and Table V) which is generally considered in a wind farm connected to large power system, is performed in the simulation analysis here. In conventional power smoothing method, an energy storage system only smoothes wind farm output fluctuations, and slow change of wind farm output is absorbed by several thermal and hydraulic power plants installed as main generators in large power system. However, since the total power rating and the number of main power generators are limited in the case of an isolated power system, power regulation may become difficult even when wind farm output fluctuation is small. Moreover, the output of main power generators should be adjusted also to maintain the amount of residual energy of storage system. If the stored energy is not regulated suitably, power balance of the isolated power system cannot be kept when the stored energy reaches full or empty level. Therefore, it can be said that the frequency stabilization in the case of an isolated power system cannot be achieved only by the conventional power smoothing scheme.

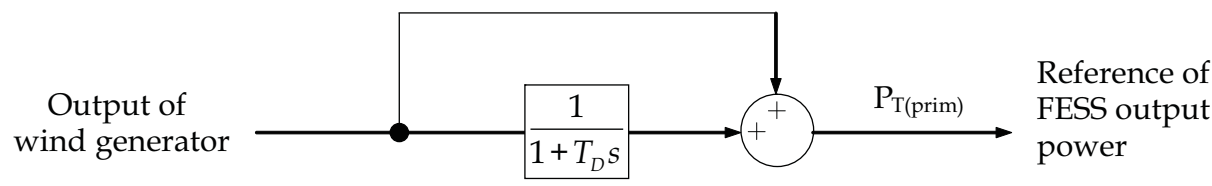

Low Pass Filter (1-order delay)

Fig. 12. Reference signal regulator of the FESS for power smoothing control

\begin{tabular}{ccc|c|c}
\hline & & & $P_{\text {ref }}<0$ & $P_{\text {ref }}>0$ \\
\hline & $W_{\text {R_FESS }}$ & $>1.3$ & 1 & 0 \\
\hline $1.3>$ & $W_{\text {R_FESS }}$ & $>0.7$ & 1 & 1 \\
\hline $0.7>$ & $W_{\text {R_FESS }}$ & 0 & 1 \\
\hline
\end{tabular}

Table V. Rule of FESS control for power smoothing 

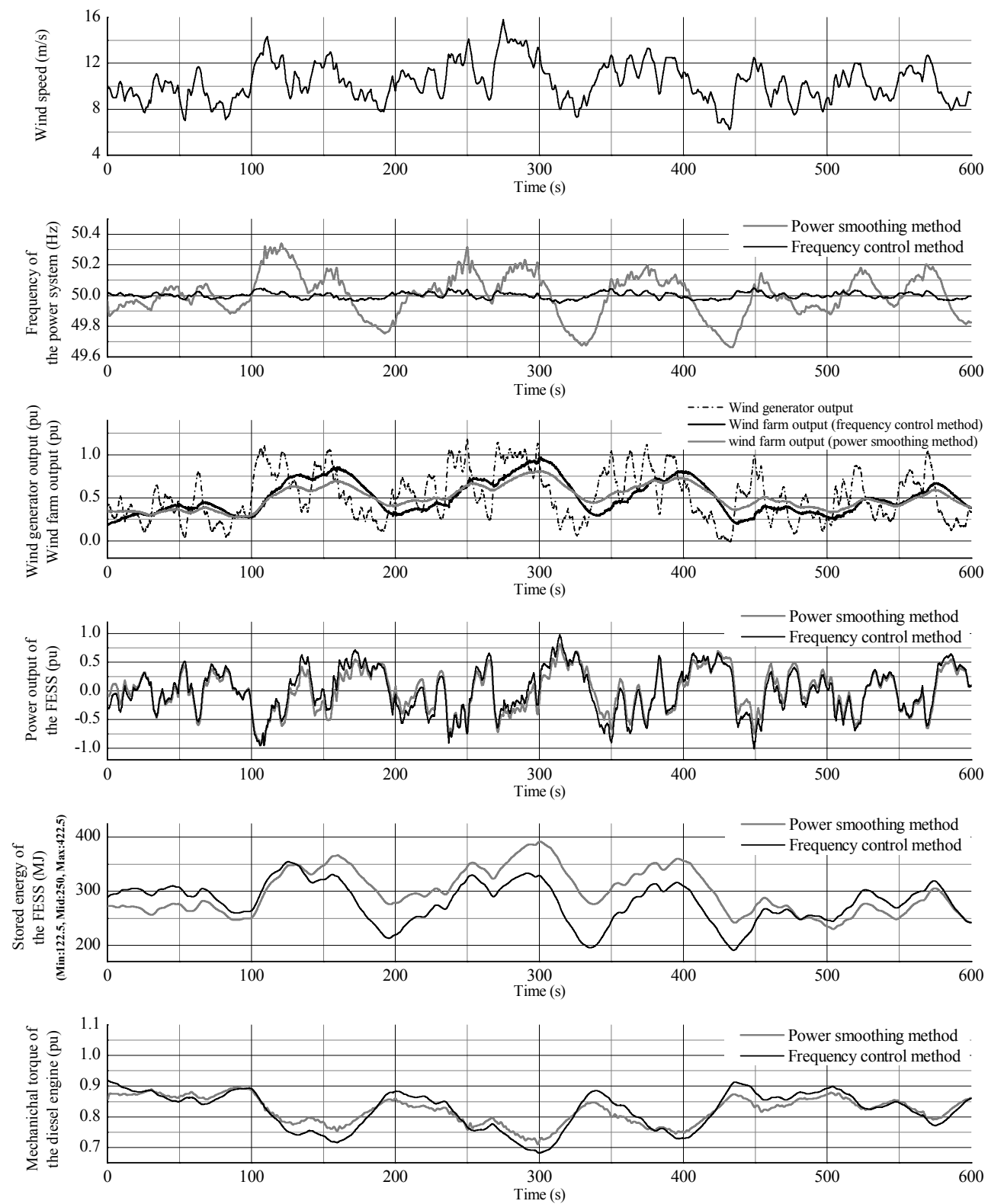

Fig. 13. System response under the frequency control method and power smoothing method 
In the comparative study, simulations by the conventional output power smoothing method have also been performed, in which the reference output from the WF to the grid is determined by inputting the net WF output into a first order delay transfer function and FESS supply the difference between the reference power and the net output to follow the WF-to-grid output to the reference value as shown in Fig. 12. Therefore block A in Fig. 7 is replaced by Fig. 12 and the rule of FESS control shown in Table I is also replaced by Table V. In the conventional method, the cooperation control with the main power plant is impossible. The power rating of FESS is chosen to be 7MVA, same as that in the frequency control method, and the time constant of the first order delay is set to $30 \mathrm{~s}$.

\section{B. Results}

Fig. 13 shows system responses under the proposed frequency control method and the conventional power smoothing method. The frequency deviation reaches about $0.3 \mathrm{~Hz}$ at the maximum in the case of the power smoothing method, but it is regulated within about $0.05 \mathrm{~Hz}$ in the case of the frequency control method. The stored energy of FESS is remained well between the maximum and the minimum levels, from which there may be a possibility that the energy storage capacity of FESS can be reduced. Responses of the prime mover output (diesel engine output) are almost the same in both methods.

\section{Summary}

This chapter has proposed a new method of network frequency regulation by using Flywheel Energy Storage System (FESS) for an isolated power system including a wind farm, and the validity of the proposed method has been evaluated by computer simulations. From the comparative study between the proposed method and the conventional output smoothing control of wind farm, it has been shown that the proposed method is very effective on the stabilization of network frequency in an isolated small power system.

The proposed method can be applied basically not only to a FESS system but also other types of energy storage system. Therefore the proposed method can contribute to expand wind energy utilization into isolated power systems like a small island.

\section{References}

[1] T. Kuwabara, A. Shibuya, H. Furuta, E. Kita, and K. Mitsuhashi : "Design and Dynamic Response Characteristics of $400 \mathrm{MW}$ Adjustable Speed Pumped Storage Unit for Ohkawachi Power Station," IEEE Transactions on Energy Conversion, Vol. 11, No. 2, pp. 376-384, June 1996.

[2] M. Kazuma, U. Yuuetsu : "Hydroelectric Power Technologies Contributing to Power System Quality Improvement", TOSHIBA REVIEW, VOL.58, NO.7, 2003.

[3] Manitoba HVDC Research Centre (http:/ / www.hvdc.ca/)

[4] R.Takahashi, J.Tamura, Y.Tada, A.Kurita: "Model Derivation of an Adjustable Speed Generator and Its Excitation Control System", Proc. of 14-th Power System Computation Conference, Session-06, paper-4, June 2002.

[5] O. Wasynczuk, D. T. Man, J. P. Sullivan : "Dynamic Behavior of a Class of Wind Turbine Generator During Random Wind Fluctuations", Trans. of IEEE on Power Apparatus and Systems, Vol. PAS-100, No.6, pp.2873-2845, June 1981. 
[6] Sanjoy Roy, O.P.Malik, G.S.Hope : "A k-Step Predictive Scheme for Speed Control of Diesel Driven Power Plants", IEEE Transactions on Industry Applications, Vol. 29, No. 2, pp. 389-396, March/ April 1993. 


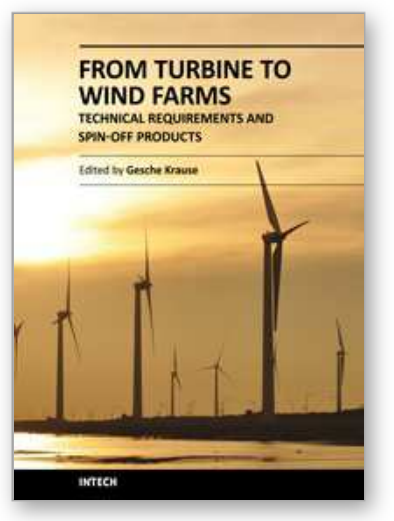

\section{From Turbine to Wind Farms - Technical Requirements and Spin- Off Products}

Edited by Dr. Gesche Krause

ISBN 978-953-307-237-1

Hard cover, 218 pages

Publisher InTech

Published online 04, April, 2011

Published in print edition April, 2011

This book is a timely compilation of the different aspects of wind energy power systems. It combines several scientific disciplines to cover the multi-dimensional aspects of this yet young emerging research field. It brings together findings from natural and social science and especially from the extensive field of numerical modelling.

\section{How to reference}

In order to correctly reference this scholarly work, feel free to copy and paste the following:

Rion Takahashi (2011). Frequency Control of Isolated Power System with Wind Farm by Using Flywheel Energy Storage System, From Turbine to Wind Farms - Technical Requirements and Spin-Off Products, Dr. Gesche Krause (Ed.), ISBN: 978-953-307-237-1, InTech, Available from:

http://www.intechopen.com/books/from-turbine-to-wind-farms-technical-requirements-and-spin-offproducts/frequency-control-of-isolated-power-system-with-wind-farm-by-using-flywheel-energy-storage-system

\section{INTECH}

open science | open minds

\author{
InTech Europe \\ University Campus STeP Ri \\ Slavka Krautzeka 83/A \\ 51000 Rijeka, Croatia \\ Phone: +385 (51) 770447 \\ Fax: +385 (51) 686166 \\ www.intechopen.com
}

\author{
InTech China \\ Unit 405, Office Block, Hotel Equatorial Shanghai \\ No.65, Yan An Road (West), Shanghai, 200040, China \\ 中国上海市延安西路65号上海国际贵都大饭店办公楼 405 单元 \\ Phone: +86-21-62489820 \\ Fax: +86-21-62489821
}


(C) 2011 The Author(s). Licensee IntechOpen. This chapter is distributed under the terms of the Creative Commons Attribution-NonCommercialShareAlike-3.0 License, which permits use, distribution and reproduction for non-commercial purposes, provided the original is properly cited and derivative works building on this content are distributed under the same license. 